\title{
SECONDARY METABOLITES WITH ANTIBACTERIAL EFFECTS FROM LEAVES OF DIFFERENT HOP CULTIVARS DURING VEGETAL PERIODS
}

\author{
EVA ÜRGEOVÁ, LUUDOVÍT POLÍVKA \\ Department of Biotechnology, University of SS. Cyril and Methodius, J. Herdu 2, \\ Trnava, SK-917 01, Slovak Republic (eva.urgeova@ucm.sk)
}

\begin{abstract}
According to the latest EU regulations it is necessary to cut down the consumption of chemically based pesticides. Several research programmes are focussed on the study of secondary metabolites of plants, which have antimicrobial or antifungal activity against microbial phytopathogens. Other reasons for using of natural biocides are the growth of resistance of phytopathogens against several pesticides; broaden microbial attacks to significant agricultural product for food industry due to the climate changes.

The presentation is focussed on the determination of the contents of secondary metabolitesleaves of several cultivars of hop - polyphenols and flavonoids. Methanol crude leaves extracts were tested on biocide effects against selected microbial phytopathogens.
\end{abstract}

Key words: hop, extracts, polyphenols, flavonoids, antibacterial effect

\section{Introduction}

According to the latest EU regulations it is necessary to cut down the consumption of chemically based pesticides. Several research programmes are focussed on the study of secondary metabolites of plants which have antibacterial or antifungal activity against microbial phytopathogens.

The plants synthesise and accumulate various secondary metabolites which are characterised by the diversity of their chemical structures, restricted distribution and protective function for an organism.

In this perspective, increasing attention is being paid to the plant called common hop (Humulus lupulus L) (MOIR, 2000). Hop compounds are effective inhibitors of Gram-positive bacteria (BATTACHARYA et al., 2003), mycobacteria (STAVRI et al., 2004) and protozoa (SRINIVASAN et al., 2005). In addition, xanthohumol has been reported to be a broad spectrum anti-infective agent working against many bacteria, viruses, fungi, and protozoa (GERHÄUSER, 2005). In the study of antimicrobial activity of essential oils from the hop plant, LAGEZAAL et al. (1992) identified their inhibitive influence on Gram-positive bacteria Bacillus subtilis and Staphylococcus aureus, as well as on the fungus Trichophyton mentagrophyles.

One of the big groups of substances contained in the hop plant is the group of polyphenol compounds, chalkones, flavanols, flavonols, and antocyanides (HOFTA et. al., 2004). Content of polyphenols in the leaves can be of potential benefit when speaking of using these as raw material for extraction of these substances (ČEH et al., 2007). The most interesting of them are flavonoids, belonging to the most widespread compounds in nature. 
The aim of these experiments was to test the influence of the vegetation period on the content of some secondary metabolites of hop, polyphenol compounds, and flavonoids, which display a wide range of biological and pharmacological properties. Biocide activity of extracts from hop leaves was tested, too.

\section{Material and methods}

\subsection{Plant material}

The samples of hop taken from the Gene Bank of the Slovak Republic in the Institute of Plant Production, Piešt'any (CVRV - VÚRV) were tested. We used the following cultivars of hop: Osvald's clones 31 (K-31) and 72 (K-72), Bor, Sládek, Zlatan, and Premiant. We collected the samples at the beginning of vegetal period (April 08), before (June 08) and during the flowering time (July 08) and at the end of the vegetal period (September 08).

\subsection{The tested phytopathogene bacteria}

For the purpose of this study we used phytopathogenic microorganisms Erwinia mallotivora CCM 2890, obtained from the Czech Collection of Microorganisms of the Masaryk University, Faculty of Science, Brno, Clavibacter michiganensis subsp. sepedonicus CPPB A098, Erwinia amylovora CPPB A203, Pectobacterium carotovorum pv. carotovorum CPPB AO86, Pseudomonas syringae pv. syringae CPPB A171, and Xanthomonas vesicatoria CPPB A085, obtained from the Collection of Phytopathogenic Bacteria and Referential Antidotes (CPPB) at the Crop Research Institute in Prague-Ruzyně, Czech Republic. Bacteria were kept as a stock culture in the refrigerator at the temperature of $8^{\circ} \mathrm{C}$.

\subsection{Extraction}

The extracts were prepared by methanol extraction in the ratio of 1:20. After extraction it was evaporated on the vacuum rotary evaporator. We dissolved this matter in ethyl acetate and water in ratio 1:1. The organic phase was evaporated. Dry matter was dissolved in methanol $(4: 3 \mathrm{w} / \mathrm{v})$ and stored in a cold store.

\subsection{Method for testing biocide effect of extracts}

The antibacterial activity of extracts was determined in vitro against a variety of phytopathogene bacteria. Antimicrobial activities were tested by the standard plate diffusion method (PIDDOCK, 1989) and zones of inhibition were measured in $\mathrm{mm}$. The biocide effect was compared with the effect of $1.2 \% \mathrm{w} / \mathrm{v}$ solution of TMTD (tetramethylthiuram disulfide), active substance of commercial pesticides. Plant extracts $(15 \mu \mathrm{l})$ were placed in metal cylinders on the surface of a media plate seeded with the organism being examined. The microorganism grows during incubation at $30^{\circ}$ $\mathrm{C}$; clear zones develop around cylinders, indicating the inhibition of growth. The size 
of the zone of inhibition caused by diffusion of agent into agar is directly related to the degree of susceptibility of an organism.

\subsection{Determination of phenol compounds}

The content of phenol substances was determined by Singelton's method (SINGELTON et al., 1965). The amount of $0.2 \mathrm{ml}$ of methanol extract was mixed with $1 \mathrm{ml}$ of Folin-Ciocalteu's reagent and $0.8 \mathrm{ml}$ of $7.5 \%(\mathrm{w} / \mathrm{v}) \mathrm{Na}_{2} \mathrm{CO}_{3}$. Absorbance was measured at $750 \mathrm{~nm}$ after 30 minutes of incubation in dark. The content of polyphenols was compared with the absorbance of galic acid.

\subsection{Determination of flavonoids}

Flavonoids were determined by Rakotoarison's method (RAKOTOARISON et al., 1997). One $\mathrm{ml}$ of methanol extract was added to $1 \mathrm{ml}$ of methanol solution of $\mathrm{AlCl}_{3} \cdot 6 \mathrm{H}_{2} 0,2 \%(\mathrm{w} / \mathrm{v})$, and absorbance was measured after 10 minutes at $394 \mathrm{~nm}$. Quercetin was taken as the standard.

\section{Results and discussion}

The first samples were tested before the flowering and the second samples were tested at the end of vegetal period. All cultivars showed different secondary metabolites during the vegetation period, their content in leaves decreased from the end of June to September (Table 1).

Table 1. Polyphenols content in hop leaves during the vegetation period.

\begin{tabular}{ccc}
\hline \multirow{2}{*}{ Cultivars } & \multicolumn{2}{c}{ Polyphenols $\left[\mathbf{m g ~ g}^{\mathbf{- 1}} \mathbf{D M}\right]$} \\
\cline { 2 - 3 } & $\mathbf{6 / 2 0 0 8}$ & $\mathbf{9} / \mathbf{2 0 0 8}$ \\
\hline$K-31$ & $6.99 \pm 0.14$ & $4.53 \pm 0.12$ \\
$K-72$ & $12.48 \pm 0.36$ & $3.03 \pm 0.09$ \\
Bor & $14.34 \pm 0.15$ & $3.77 \pm 0.20$ \\
Sládek & $12.32 \pm 0.22$ & $3.30 \pm 0.12$ \\
Zlatan & $13.38 \pm 0.14$ & $3.57 \pm 0.11$ \\
Premiant & $9.50 \pm 0.33$ & $4.68 \pm 0.06$ \\
\hline
\end{tabular}

The maximum of content of polyphenols was found in cultivar Bor, the cultivar with a high content of bitter acids, at the beginning of the vegetal period; it was more than twice of the content of cultivar K-31. The content of polyphenols at the end of the vegetation period was similar in all the tested hop cultivars.

The experiment took place in 2008. Some relevant data from 2007 were included for comparison (Fig. 1).

Phenol substances were found in the interval between $5.00-8.83 \mathrm{mg} \mathrm{g}^{-1}$ of dry matter in 2007 compared to 9.50 to $14.34 \mathrm{mg} \mathrm{g}^{-1}$ of dry matter in 2008 in leaves before flowering, and from 0.90 to $2.25 \mathrm{mg} \mathrm{g}^{-1}$ of dry matter in 2007 compared to $3.03-4.68$ $\mathrm{mg} \mathrm{g}^{-1}$ of dry matter in 2008 in leaves at the end of the vegetal period. In the year 
2008, there was less sunshine than in 2007 and there were more showers at the beginning and also during the time of flowering than in 2007. The quantity of phenol substances was higher in 2008 than in 2007. The highest content of polyphenols was detected in cultivar Bor at the beginning of the vegetation period in 2008.

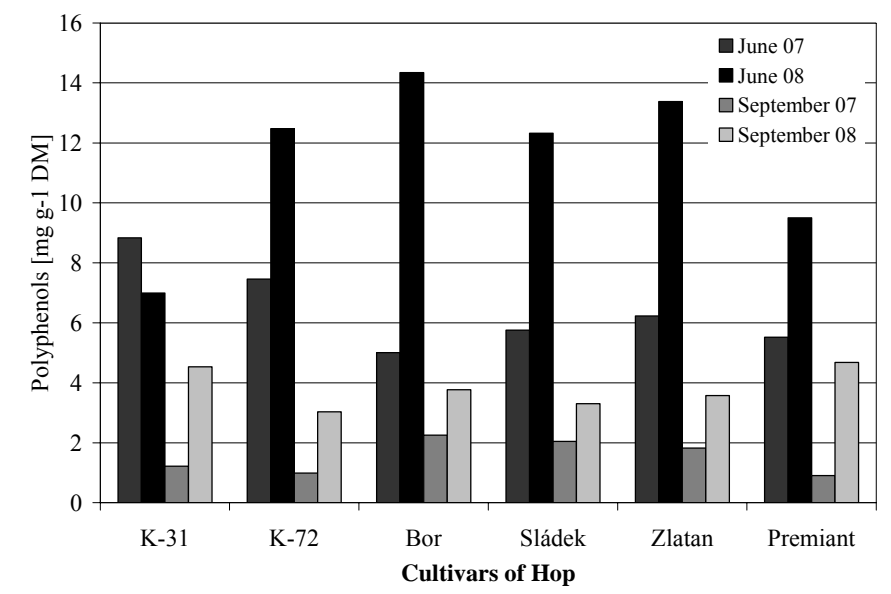

Fig. 1. Polyphenol content in hop leaves in 2007 and 2008.

Flavonoid content in leaves was similar, but different. We noted a decline during the vegetal period in both cases, as well as in phenol substances (Table 2).

Table 2. Content of flavonoids in hop leaves in 2007 and 2008.

\begin{tabular}{ccccc}
\hline Cultivars & \multicolumn{4}{c}{ Flavonoids [mg g-1 DM] } \\
\cline { 2 - 5 } & $\mathbf{6 / 0 7}$ & $\mathbf{6 / 0 8}$ & $\mathbf{9 / 0 7}$ & $\mathbf{9 / 0 8}$ \\
\hline$K-31$ & $6.37 \pm 0.51$ & $0.24 \pm 0.02$ & $0.65 \pm 0.02$ & $0.10 \pm 0.01$ \\
$K-72$ & $6.31 \pm 0.49$ & $1.43 \pm 0.05$ & $0.48 \pm 0.02$ & $0.20 \pm 0.01$ \\
Bor & $3.45 \pm 0.12$ & $0.15 \pm 0.01$ & $0.71 \pm 0.01$ & $0.16 \pm 0.02$ \\
Sládek & $3.24 \pm 0.21$ & $0.25 \pm 0.01$ & $0.76 \pm 0.01$ & $0.15 \pm 0.01$ \\
Zlatan & $5.03 \pm 0.22$ & $0.14 \pm 0.01$ & $0.61 \pm 0.01$ & $0.13 \pm 0.01$ \\
Premiant & $2.13 \pm 0.09$ & $0.19 \pm 0.01$ & $0.72 \pm 0.01$ & $0.18 \pm 0.01$ \\
\hline
\end{tabular}

The quantity of flavonoids was higher in 2007. The content of flavonoids was within the range of $2.13-6.37 \mathrm{mg} \mathrm{g}^{-1}$ of dry matter in the leaves before flowering in 2007 , and 0.14 to $1.43 \mathrm{mg} \mathrm{g}^{-1}$ of dry matter in 2008 . The ranges decreased to $0.48-$ $0.76 \mathrm{mg} \mathrm{g}^{-1}$ of dry matter of flavonoids at the end of vegetation in 2007 . Similarly, the interval of flavonoid content at the end of the vegetal period was 0.10 to $0.20 \mathrm{mg} \mathrm{g}^{-1}$ of dry matter in 2008 .

Antibacterial activity was tested during the vegetation of hop plants. The marked inhibition effect of the extract of cultivar Bor on Erwinia mallotivora, $89 \%$ of inhibition effect of the standard TMTD, was noticed. The extracts from cultivars K$31 \mathrm{~A}$ had a similar effect on these bacteria, $67 \%$ of inhibition effect of the standard TMTD (Fig. 2.). 


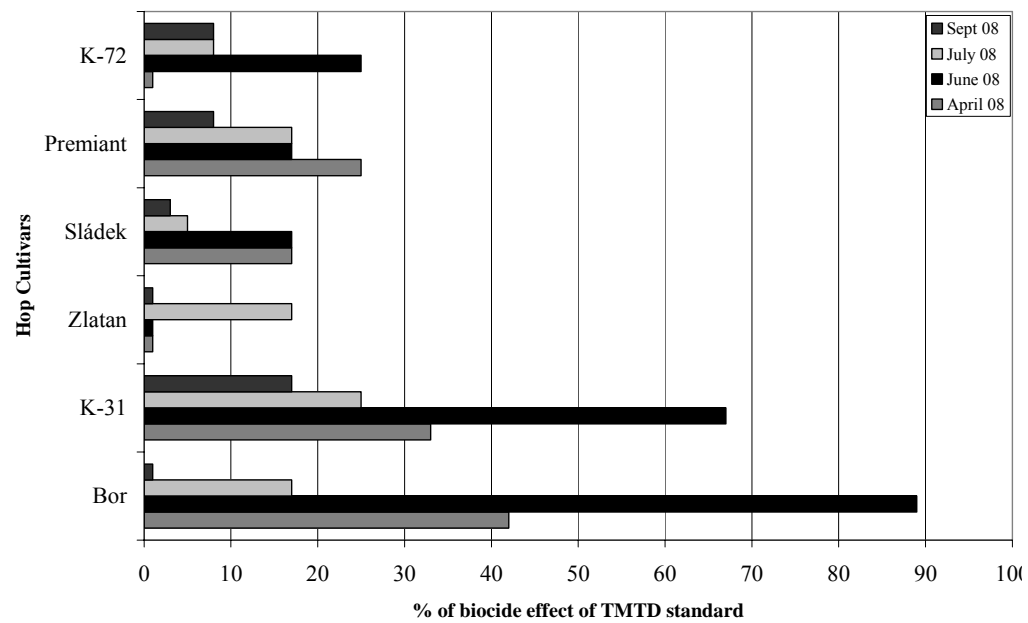

Fig. 2. Biocide effect of hop extracts on the growth of Erwinia malotivora.

The average size of inhibition zones of extracts from leaves at the beginning of vegetation (April 08) was lower than the average size of extracts before the flowering time (June 08) (Table 3).

Tab. 3. Antibacterial effect of hop extracts during the vegetal period described as zones without the growth of bacteria on the agar plate in $\mathrm{mm}$.

\begin{tabular}{|c|c|c|c|c|c|c|c|}
\hline \multirow{2}{*}{ Bacteria } & \multirow{2}{*}{$\begin{array}{l}\text { vegetal } \\
\text { period }\end{array}$} & \multicolumn{6}{|c|}{ Hop cultivars } \\
\hline & & $K-31$ & $K-72$ & Bor & Sládek & Zlatan & Premiant \\
\hline \multirow{3}{*}{ E. amylovora } & April 08 & 3 & 2 & $<1$ & 2 & 2 & 2 \\
\hline & June 08 & 4 & 3 & 2 & 4 & 2 & 2 \\
\hline & Sept 08 & $<1$ & 1 & 2 & $<1$ & $<1$ & 1 \\
\hline \multirow{3}{*}{$X$. vesicatoria } & April 08 & 3 & 3 & 3 & 2 & 2 & $<1$ \\
\hline & June 08 & 4 & 3 & 4 & 2 & 3 & 3 \\
\hline & Sept 08 & 4 & 2 & $<1$ & $<1$ & $<1$ & 4 \\
\hline \multirow{3}{*}{$\begin{array}{l}\text { P. carotovorum } \\
\text { subsp. } \\
\text { carotovorum }\end{array}$} & April 08 & 4 & $<1$ & 2 & $<1$ & $<1$ & 2 \\
\hline & June 08 & 4 & 5 & 3 & 1 & 6 & 4 \\
\hline & Sept 08 & 2 & 2 & $<1$ & 4 & $<1$ & 4 \\
\hline \multirow{3}{*}{$\begin{array}{c}\text { P. syringae pv. } \\
\text { syringae }\end{array}$} & April 08 & 2 & $<1$ & $<1$ & $<1$ & 2 & 4 \\
\hline & June 08 & 4 & 3 & 3 & 2 & 3 & 4 \\
\hline & Sept 08 & $<1$ & 2 & 1 & 2 & $<1$ & 2 \\
\hline \multirow{3}{*}{$\begin{array}{c}C . \\
\text { michiganensis } \\
\text { subsp. } \\
\text { sepedonicus }\end{array}$} & April 08 & $<1$ & $<1$ & $<1$ & 2 & 2 & $<1$ \\
\hline & June 08 & 2 & 3 & 1 & 3 & 2 & 3 \\
\hline & Sept 08 & 1 & 1 & $<1$ & 1 & 2 & 2 \\
\hline
\end{tabular}

The inhibition effect of the extracts from hop leaves at the end of the vegetation period was minor. 


\section{Conclusions}

The comparison of the results obtained during two years proved that the concentration of secondary metabolites, phenol substances and flavonoids depended mainly on the vegetal period. The influence of climatic conditions on the contents of these secondary metabolites of hop leaves was verified. The contents of these constituents were different in identical cultivars, compared to the years 2007 and 2008.

The results of antibacterial activity suggested that this effect related mainly with sensibility of the bacterial strain and cultivar of hop. We observed the influence of the vegetation period, too.

Acknowledgement: This work was financially supported within the grants VEGA 1/0436/08 and AV 4/2024/08.

\section{References}

BHATTCHARYA, S., VIRANI, S., ZAVRO, M., HAAS, G., J.: Inhibition of Streptococcus Mutans and other oral Streptococci by hop (Humulus Lupulus L.) constituents. Econ. Bot., 57, 2003, 118-125.

ČEH, B., KAČ, M., IZTOK, J., KOŠIR, L., ABRAM, V.: Relationships between xanthohumol and polyphenol content in hop leaves and hop cones with regard to water supply and cultivar. Int. J. Mol. Sci., 8, 2007, 989-1000.

GERHAUSER, C.: Broad spectrum anti-infective potential of xanthohumol from hop (Humulus lupulus L.) in comparison with activities of other hop constituents and xanthohumol metabolites. Mol. Nutr. Food Res., 49, 2005, 827-31.

HOFTA, P., DOSTÁLEK P., BASAŘOVÁ, G.: Xantohumol - chmelová pryskyřice nebo polyfenol? Chem. Listy, 2004, 98, 825-830.

LANGEZAAL, C.R.; CHANDRA, A.; SCHEFFER, J.C.: Antimicrobial screening of essential oils and extracts of some Humulus lupulus L. cultivars. Pharm. Weekbl., 1992, 14, 353-356.

MOIR, M.: Hops - A millenium review. J. Am. Soc. Brew. Chem., 58, 2000, 131-146.

PIDDOCK, J. V. L.: Techniques used for the determination of antimicrobial resistance and sensitivity in bacteria. J. Appl. Bacteriol., 68, 1989, 307-318.

RAKOTOARISON, D., A., GRESSIER, B., TROTIN, F., BRUNET, C., DINE, T., LUYCKX, M., VASSEUR, J., CAZIN, M., CAZIN, J., C., PINKAS, M.: Antioxidant activites of polyphenolic extracts from flowers, in vitro callus and cell suspension cultures of Crataegus monogyna. Pharmazia, 52, 1997, 60-63.

SINGLETON, V., L., ROSSI, J., A.: Colorimetry of total phenolics with phosphomolybdic-phosphotungstic acid reagents. Am. J. Enol. Vitic, 16, 1965, 144-158.

SRINIVASAN, V., GOLDBERG, D., HAAS, G.J.: Contributions to the antimicrobial spectrum of hop constituents. Econ. Bot., 58, 2004, S230-S238.

STAVRI, M., SCHNEIDER, R., O'DONNELL, G., LECHNER, D., BUCAR, F., GIBBONS, S.: The antimycobacterial components of hops (Humulus lupulus L.) and their dereplication. Phytother. Res., 18, 2004, 774-776. 